\title{
The inflammatory response of the pulp after direct capping with platelet-rich plasma and enamel matrix derivative: A controlled animal study
}

\author{
Murat Maden $^{1}$, Ekim Onur Orhan ${ }^{2 *}$, İhsan Furkan Ertuğrul ${ }^{1}$, Burcu Sengüven ${ }^{3}$ \\ ${ }^{1}$ Department of Endodontics, Faculty of Dentistry, Süleyman Demirel University, Isparta, Eskişehir, Turkey \\ ${ }^{2}$ Department of Endodontics, Faculty of Dentistry, Eskişehir Osmangazi University, Eskişehir, Turkey \\ ${ }^{3}$ Department of Oral Pathology, Gazi University, Ankara, Turkey \\ Email: *eonurdentus@hotmail.com
}

Received 28 November 2013; revised 30 December 2013; accepted 10 January 2014

Copyright (C) 2014 Murat Maden et al. This is an open access article distributed under the Creative Commons Attribution License, which permits unrestricted use, distribution, and reproduction in any medium, provided the original work is properly cited. In accordance of the Creative Commons Attribution License all Copyrights @ 2014 are reserved for SCIRP and the owner of the intellectual property Murat Maden et al. All Copyright (C) 2014 are guarded by law and by SCIRP as a guardian.

\section{ABSTRACT}

Aims: To evaluate the inflammatory response of the exposed pulp of incisor teeth in rats after direct pulp capping, using platelet rich plasma (PRP), enamel matrix derivate (EMD), mineral trioxide aggregate (MTA) and calcium hydroxide $\left(\mathrm{Ca}(\mathrm{OH})_{2}\right)$. Methods: The study was conducted on 36 Wistar albino rats with a total of 144 incisor teeth. The pulps of 96 teeth of the rats were perforated and capped with different agents. Serving as the positive control group, the pulps of 24 teeth were only perforated and capped without capping agents, whereas the pulps of 24 teeth were used as the negative control group without being perforated (without any process). The research was ended with the extracting of the teeth on the 7th day - 28th day. The teeth were taken to the routine and histological follows; cross sections were prepared and painted with hematoxylen \& eosin. All of the sections were evaluated in terms of inflammatory reaction by histologic analysis taken by light microscope. Statistical analysis was used. The normal distribution of all data was tested with the Mann Whitney $U$ and the differences between the groups were analyze dusing Kruskal Wallis test at 0.05 level. Results: There are no statistically significant differences in terms of inflammation type and necrosis among the treatment groups on 7 days' post capping. However, improved inflammatory cell accumulation, hyperemia and lowest necrosis were observed from the samples treated with PRP ( $p<0.05)$. Conversely, the EMD group indicated that the criteria of inflammation scores and hyper-

${ }^{*}$ Corresponding author. emia were higher in the 28th day $(p<0.05)$. Conclusions: Most of cells accumulating in the PRP group and most necrosis were seen in the EMD group. These new PRP materials might serve as pulp capping biomaterials to induce initial healing response in the future.

\section{KEYWORDS}

Enamel Matrix Derivate; Platelet Rich Plasma; Mineral Trioxide Aggregate; Inflammatory Response; Direct Pulp Capping

\section{INTRODUCTION}

Vital pulp therapy includes direct and indirect pulp-capping, pulpotomy and therapy that minimize pulpal injury by protecting the pulp from the toxic effects of chemical, bacterial, mechanical or thermal insult [1]. Therefore, vital pulp therapy is aimed at treating reversible pulpal injures by sealing the pulp and stimulating the formation of tertiary dentinal formation [2].

Conservative pulp therapy is designed to maintain viable coronal and radicular pulp tissue. Calcium hydroxide $\left(\mathrm{Ca}(\mathrm{OH})_{2}\right)$ and $\mathrm{Ca}(\mathrm{OH})_{2}$ compounds are the gold standards used to preserve vitality through pulp capping since 1920 [3]. Numerous subsequent studies have demonstrated dentinal bridge formations in about 50\% - 87\% of cases capped with various $\mathrm{Ca}(\mathrm{OH})_{2}$ formulations [4-6]. However, $\mathrm{Ca}(\mathrm{OH})_{2}$ and their formulations have been known as having a limited effect on pulp tissue repair.

Some research for biocompatible agents that can induce in vivo pulp repair mechanisms has produced a va- 
riety of materials. Mineral trioxide aggregate (MTA) has been a promising material among these because of its characteristics as a direct pulp capping agent compared with $\mathrm{Ca}(\mathrm{OH})_{2}$ controls in several animal models [7-9].

Enamel extracellular matrix has been related to important biologic functions in tooth development [10] and successfully used in dentistry in the form of enamel matrix derivative (EMD) to incite natural cementogenesis to restore a fully functional periodontal ligament, cementum, and alveolar bone [11] in the treatment of intrabony defects in patients with severe and advanced periodontitis, through regeneration of the affected tissues [12-14]. When applied to denuded root surfaces, EMD forms a matrix that locally facilitates regenerative responses in the adjacent periodontal tissues [15]. EMD is also used in cases of dental reimplantation [16] and as a material of direct pulp capping (DPC) in animal teeth [17-19].

The descriptions of various bioactive molecules including growth factors lead to exciting alternative treatments of dentin-pulp complex $[20,21]$. The usage of growth factors alone in regenerative treatment approaches tried to be developed imitating the physiological events of the body has been questioned. Platelet rich plasma (PRP) recommended as a remedy for these kinds of researches is encountered as a rich source for growth factors $[22,23]$. Under economic and treatment conditions, PRP can be obtained in a short time from the patient's own blood. The usage of this material in vital pulp treatments has not been encountered, though it is used in many areas in dentistry including maxillo-facial surgery, oral surgery and periodontology [24].

There are very few data about the effects of endogenous growth factors on vital pulp therapy, and still they are often controversial. The aim of the study was to evaluate the inflammatory response to EMD, PRP compared to that of $\mathrm{Ca}(\mathrm{OH})_{2}$ and MTA in rat incisor teeth.

\section{METHODS}

Firstly, our project was approved by the local ethical committee of animal experiments. A total of one hundred and forty-four healthy, mature, maxillary and mandibular incisor teeth of thirty-six Wistar albino rats (a year-old, 300 grams or greater) were chosen for this experiment.

Following the anesthesia by intra-peritoneal injection of 2, 2, 2-tribromoethanol 2-methyl 2-butanol (Avertine ${ }^{\circledR}$; Sigma Aldrich, Lyon, France) $\left(0.017 \mathrm{~mL} \cdot \mathrm{g}^{-1}\right)$, their blood samples were taken for preparing PRP.

\subsection{Procedure of PRP Preparations}

For preparing the PRP, special collection kit (Curasan AG PRP kit, Kleinostheim, Germany) and multipurpose centrifuge device (Curasan Centrifuge ${ }^{\circledR}$, Kleinostheim, Germany) were used. We took peripheral blood (1 mL) by directly into $3.8 \%$ (wt/vol) sodium citrate ( $1 \mathrm{vol}: 9 \mathrm{vol})$ according to the manufacturer guidelines. PRP was prepared by centrifugation sequence at 1300 cycle $\times 10 \mathrm{~min}$ and 2000 cycle $8 \mathrm{~min}$ at room temperature and the $0.5 \mathrm{ml}$ plasma fraction located just above the sedimented red cells but not including the Buffy coat was collected. Glass tubes containing the PRP were incubated at $37^{\circ} \mathrm{C}$ in the presence of $22.8 \mathrm{mM} \mathrm{CaCl}_{2}$ to start retraction. PRP was prepared separately for each animal.

\subsection{In Vivo Experiments}

Isolation was performed to the incisor teeth with individual paper dams. Class V cavities were preparated on buccal side with a carbide bur ISO 004 (Mani Dia-Burs, Mani Inc. Tochigiken, Japan) of the teeth until the pulp was visible through the transparency of the dentin floor of the cavity under $10 \times$ magnification in the operation microscope (Carl Zeiss Meditec AG, Jena, Germany). A pulp exposure was subsequently created mechanically using an endodontic explorer: this approach enabled the control of pulp exposure size using the tip of explorer approximately $0.15 \mathrm{~mm}$ diameter (DG16, Hu-Friedy, Chigago, IL, USA).

Direct pulp capping (DPC) was performed using with PRP, EMD, $\mathrm{Ca}(\mathrm{OH})_{2}$ and MTA. The procedure was derived from published methods $[4,20]$. The exposed pulp tissue was covered with EMD (Emdogain ${ }^{\circledR}$ gel, Biora AB, Malmö, Sweden). PRP were placed in contact with the pulp carried with high absorbable sterile collagen membrane (Suprasorb $C^{\circledR}$, Lohmann \& Rausher International GmvH \& Co., Rengsdrof, Germany). $\mathrm{Ca}(\mathrm{OH})_{2}\left(\mathrm{Dycal}^{\circledR}\right.$, DENTSPLY, Kontanz, Germany) and MTA (ProRoots MTA, Dentsply, Tulsa Dental, Tulsa, OK, USA) were placed in contact with the pulp using the tip of a probe and condensed gently with a sterile paper point. A small amount of MTA was placed with a tiny ball applicator over the exposure. Subsequently, the cavities were sealed with reinforced Zinc Eugenol cement (IRM, Caulk Dentsply, Milford, DE, USA) according to its instructions. Animals were placed in individual cages until they recovered from the anesthetic and to aid recovery.

As a positive control, the pulp capping procedure was performed on the teeth of six animals in the absence of any agents, whereas as a negative control, no process was performed to the animals.

Treated animals were sacrificed at increasing time periods following 18 animals on the $7^{\text {th }}$ day postoperatively and 18 animals on the twenty eighth postoperatively.

Prior to the dental tissue extraction animals were sacrificed, after deep anesthesia, by intra-cardiac perfusion with 4\% paraformaldehyde (PFA) (Sigma-Aldrich Co., St. Louis, MO, USA) in phosphate-buffered saline (PBS) $0.1 \mathrm{~mol} \cdot \mathrm{L}^{-1}(\mathrm{pH}=7.4)$ through the left ventricle, using 
sterile syringe.

\subsection{Histologic Evaluation}

Obtained from samples were fixated in $10 \%$ buffered formalin solution after 24 - 72 hours in 10\% formic acid, decalcification was achieved. $10 \%$ acetic acid solution for three days was changed to 2 - 3 weeks. Decalcificated samples were washed in running water overnight, embedded in paraffin following the routine tissue procedures using rotary tissue processor (Sakura Finetek Japan Co. Tokyo, Japan) were followed. Gradually 10 sections of about 4-micron thickness were taken from the tissues for Hematoxylin \& Eosin staining. In all cases, histopathological evaluation was performed under a light microscope (Leica DM 4000B Leica Microsystems GmbH. Wetzlar, Germany). Hematoxylin and eosin stained sections of samples were evaluated as soft tissue changes in pulp tissue using the modified criteria of Hasheminia et al. [25]. These criteria were modified for the rats' incisor teeth (Table 1).

\subsection{Statistical Analyses}

The normal distribution of all data was tested with the Mann Whitney U test. After confirming normal distribution, the statistical differences between the groups were analyzed by analysis of variance, and paired comparisons were performed using Kruskal Wallis test. The ChiSquare test was performed All statistical analyses was performed using the SPSS 14.0 program (SPSS Inc, Chicago, IL, USA), and the diagrams were created with the Microsoft Excel program. Data are expressed as mean \pm SD. Differences were considered to be statistically significant at $p<0.05$.

\section{RESULTS}

\section{Histopathological Findings}

Control Groups: Twenty-four teeth of the control group were examined histopathologically and time-dependently to compare untreated dental pulp tissue with any agents-applied pulp tissue (Table 2). At all-time points the odontoblasts displayed regularly arrangement, the capillaries in the pulp tissue demonstrated no congestion, and no inflammation or calcification was observed in negative control group samples (Figure 1).

Inflammation parameters were observed and the mixture of acute and chronic inflammation parameters showed the highest percentage in the positive controls (Table $2)(p<0.05)$. Although intensive acute and chronic inflammatory cells' accumulation was seen, severe capillary congestion and necrosis were not scored in any samples of this group (Figure 2).

The 7-Day Groups: The statistical analyses of 7-day
Table 1. This chart was modified by the criteria of pulpinflammation [25].

\begin{tabular}{cc}
\hline Inflammation Type & Scores \\
without inflammation & $\mathbf{0}$ \\
acute inflamasyon & $\mathbf{1}$ \\
chronic inflamasyon & $\mathbf{2}$ \\
mixed inflamation & $\mathbf{3}$ \\
Intensity & \\
Mild 0 - 30 inflammatory cells & $\mathbf{1}$ \\
Moderate 30 - 60 inflammatory cells & $\mathbf{2}$ \\
Severe $60+$ inflammatory cells & $\mathbf{3}$ \\
Hyperemia & \\
1 - 15 blood vessels & $\mathbf{1}$ \\
15 - 30 blood vessels & $\mathbf{2}$ \\
$30+$ blood vessels & $\mathbf{3}$ \\
Necrosis & $\mathbf{1}$ \\
without necrosis & $\mathbf{0}$ \\
signs of necrosis &
\end{tabular}

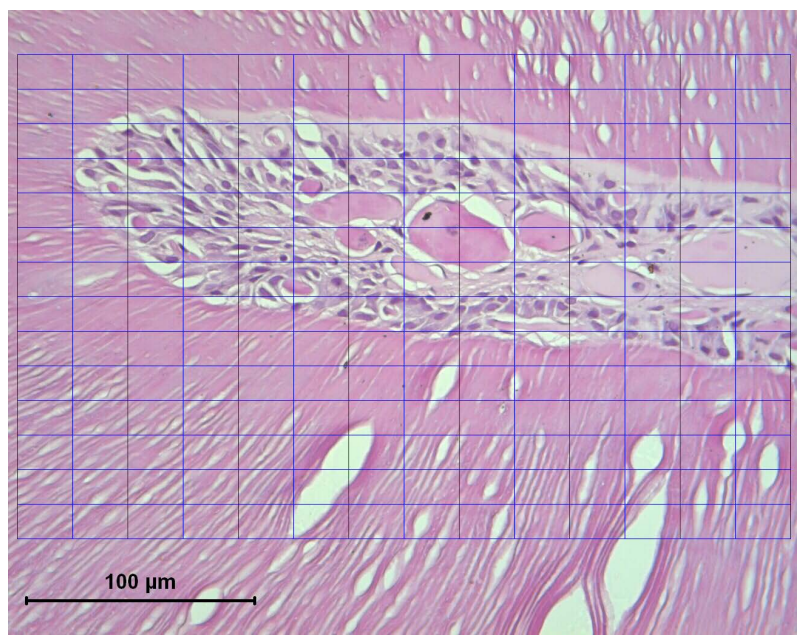

Figure 1. Representative photograph is incisor tooth of rat dental pulp in negative controls. Note the odontoblasts displayed regularly arrangement in the rat dental pulp tissue $(\mathrm{H} \& \mathrm{E}$ stain: original magnification $\times 100$ ).

samples are presented in Table 3. There are statistically significant differences in inflammation type, and hyperemia in the PRP group at 7-day post capping. Moreover, acute inflammatory cells were seen mostly in the PRP group $(p<0.05)$. The comparison of all the samples indicated that MTA and EMD showed lower hyperemia scores PRP and $\mathrm{Ca}(\mathrm{OH})_{2}(p<0.05)$. Congestion of capillaries both in the odontoblastic layer and the central 
Table 2. According to the time parameters, the number of frequency and percentages are shown below in both experimental groups and control groups.

\begin{tabular}{|c|c|c|c|c|}
\hline & $\begin{array}{c}7^{\text {th }} \text { day experimental groups } \\
(n=48)\end{array}$ & $\begin{array}{l}28^{\text {th }} \text { days experimental groups } \\
\qquad(n=48)\end{array}$ & $\begin{array}{l}\text { Negative control } \\
\quad(n=24)\end{array}$ & $\begin{array}{l}\text { Positive Control } \\
\quad(n=24)\end{array}$ \\
\hline Inflammation Type & & Frequency-(percentage) & & \\
\hline without inflammation & $9(19 \%)^{\mathrm{wm}}$ & $7(15 \%)^{\mathrm{wm}}$ & $24(100 \%)$ & $4(17 \%)$ \\
\hline acute inflamasyon & $14(29 \%)^{\mathrm{m}}$ & $12(25 \%)^{\mathrm{m}}$ & - & $4(17 \%)$ \\
\hline chronic inflamasyon & $10(21 \%)^{\mathrm{m}}$ & $10(21 \%)^{\mathrm{m}}$ & - & $3(13 \%)$ \\
\hline mixed inflamation & $7(15 \%)^{\mathrm{m}}$ & $8(17 \%)^{\mathrm{m}}$ & - & $11(46 \%)$ \\
\hline \multicolumn{5}{|l|}{ Intensity } \\
\hline Mild 0 - 30 inflammatory cells & $16(33 \%)^{\mathrm{wm}}$ & $14(29 \%)^{\mathrm{wm}}$ & $23(96 \%)$ & $10(42 \%)$ \\
\hline Moderate 30 - 60 inflammatory cells & $15(31 \%)^{\mathrm{twm}}$ & $11(23 \%)^{\mathrm{twm}}$ & $1(4 \%)$ & $1(4 \%)$ \\
\hline Severe $60+$ inflammatory cells & $9(19 \%)^{t}$ & $4(8 \%)^{t}$ & - & - \\
\hline \multicolumn{5}{|l|}{ Hyperemia } \\
\hline 1 - 15 blood vessels & $12(25 \%)^{\mathrm{wm}}$ & $15(31 \%)^{\mathrm{wm}}$ & $17(71 \%)$ & $1(4 \%)$ \\
\hline 15 - 30 blood vessels & $19(40 \%)^{\mathrm{t}}$ & $15(31 \%)^{\mathrm{t}}$ & $7(29 \%)^{t}$ & $7(29 \%)^{t}$ \\
\hline 30+ blood vessels & $9(19 \%)^{t}$ & $7(15 \%)^{t}$ & - & $3(13 \%)^{t}$ \\
\hline \multicolumn{5}{|l|}{ Necrosis } \\
\hline without necrosis & $12(25 \%)^{\mathrm{wmt}}$ & $36(75 \%)^{\mathrm{wmt}}$ & $24(100 \%)$ & $11(46 \%)$ \\
\hline signs of necrosis & $8(17 \%)^{\mathrm{mt}}$ & $11(23 \%)^{\mathrm{mt}}$ & - & $13(54 \%)$ \\
\hline
\end{tabular}

${ }^{\mathrm{t}} p<0.05 ;{ }^{\mathrm{w}} p<0.001$ versus negative control; ${ }^{\mathrm{m}} p<0.001$ versus positive control.

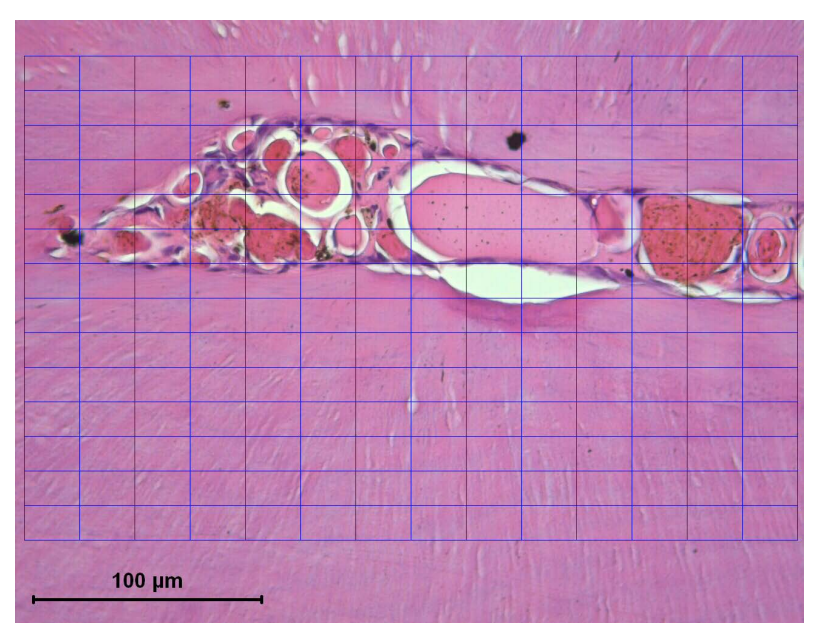

Figure 2. Representative photograph is incisor tooth of rat dental pulp in positive controls. Note the severe congestion of capillary, irregular odontoblastic arrangement, are seen in the rat dental pulp tissue $(\mathrm{H} \& \mathrm{E}$ stain: original magnification $\times 100$ ).

portion of dental pulp was noted in all groups. The scores of hyperemia ranged depending on the diffusion of capping material into pulp tissue (Figure 3). Abscess was not observed in any samples.

The 28-Day Groups: In inflammatory changes, al-
Table 3. Kruskal Wallis analyses of soft tissue responses. Data from incisors examined 7-day following the pulp capping procedure is shown. The values of soft tissue scores are mean, standard deviation values for the number of subjects listed under Sample. In general the lower score is the better in tissue response. Calcium hydroxide $\left(\mathrm{Ca}(\mathrm{OH})_{2}\right)$, enamel matrix derivative (EMD), mineral trioxide aggregate (MTA), and platelet rich plasma (PRP).

\begin{tabular}{|c|c|c|c|c|c|}
\hline \multirow{2}{*}{ 7-Day } & \multirow{2}{*}{$n$} & \multicolumn{2}{|c|}{ Inflammation } & \multirow{2}{*}{ Hyperemia } & \multirow{2}{*}{ Necrosis } \\
\hline & & Type & Intensity & & \\
\hline PRP & 12 & $1.22 \pm 0.97^{\mathrm{a}}$ & $2.60 \pm 0.70^{x}$ & $2.20 \pm 0.79^{\mathrm{d}}$ & $0.58 \pm 0.50^{\varsigma}$ \\
\hline EMD & 12 & $1.30 \pm 0.95^{\mathrm{ab}}$ & $1.26 \pm 0.79^{y}$ & $1.44 \pm 0.53^{p}$ & $0.52 \pm 0.33^{\varsigma}$ \\
\hline MTA & 12 & $1.36 \pm 1.21^{\mathrm{b}}$ & $1.50 \pm 0.53^{y}$ & $1.60 \pm 0.70^{\mathrm{ps}}$ & $0.38 \pm 0.14^{\mathrm{s}}$ \\
\hline $\mathrm{Ca}(\mathrm{OH})_{2}$ & 12 & $1.44 \pm 1.01^{\mathrm{c}}$ & $1.45 \pm 0.52^{y}$ & $1.91 \pm 0.70^{\text {sd }}$ & $0.47 \pm 0.27^{\varsigma s}$ \\
\hline
\end{tabular}

The same superscript letters are demonstrated no significant differences $(p<$ $0.05)$.

though the values of inflammation degrees, hyperemia and necrosis were decreased from 7-day results, there was no statistically significant difference between PRP, MTA, and $\mathrm{Ca}(\mathrm{OH})_{2}$ groups (Table 3$)$. Only the PRP group of samples presented the lowest necrosis $(p<0.05)$ and the comparison of the 28-day samples, the EMD group 


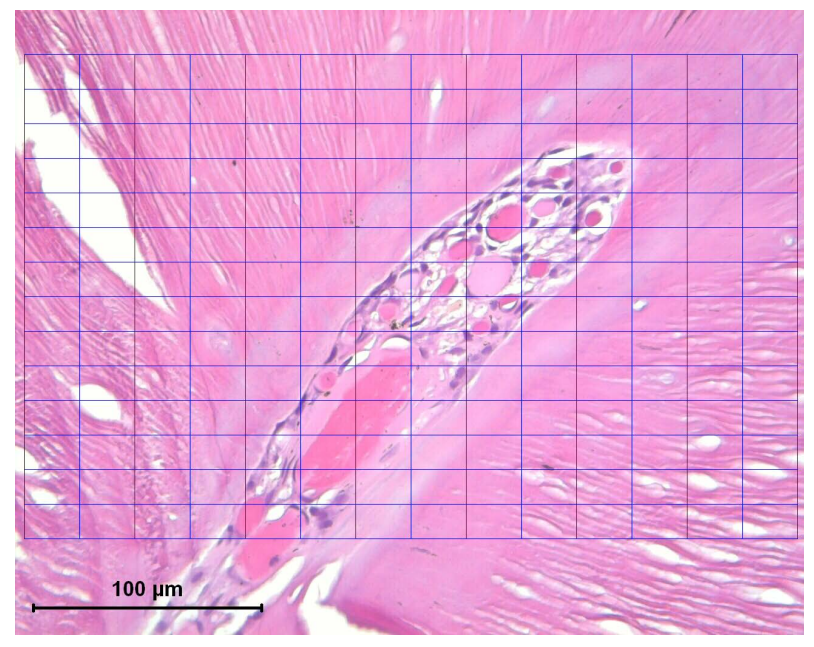

Figure 3. Representative photograph is incisor tooth of rat dental pulp in PRP group at 7-day. Note the moderate congestion of capillary, regular odontoblastic arrangement is seen. There also could be seen sign of reparative dentin formation in the rat dental pulp tissue ( $\mathrm{H} \& \mathrm{E}$ stain: original magnification $\times 100$ ).

indicated higher in the criteria of inflammation scores and hyperemia presented in Table 4 (Figure 4) $(p<$ 0.05).

\section{DISCUSSION}

Rat teeth are a valid model to histologically evaluate the outcome of direct pulp capping. In this study, incisor teeth were used because pulp capping was easy to perform. Animal incisors were used in some DPC studies [26-28]. As to cavity preparation, only Class V cavities were prepared in this study, because the procedure was easy to perform and occlusal forces during biting could be avoided [17].

The mechanism of pulp repair using $\mathrm{Ca}(\mathrm{OH})_{2}$ as a direct pulp capping agent is still not well understood. However, it has been reported that the high alkaline $\mathrm{pH}$ of $\mathrm{Ca}(\mathrm{OH})_{2}$ solutions can solubilise and release some proteins and growth factors from dentin. These events may be responsible for the pulp repair and hard tissue barrier formation [29]. Due to its high $\mathrm{pH}, \mathrm{Ca}(\mathrm{OH})_{2}$ induces a coagulation necrosis layer when in direct contact with pulp tissue [30]. Cells in contact with $\mathrm{Ca}(\mathrm{OH})_{2}$ are killed due to its alkaline $\mathrm{pH}$, forming a necrotic layer (cauterization zone) of variable thickness. Then, rather than the pulp capping agent $\left(\mathrm{Ca}(\mathrm{OH})_{2}\right)$, the subjacent pulp tissue is responsible for the pulpal healing associated with hard tissue barrier formation [31]. Classical microscopic studies have shown that $\mathrm{Ca}(\mathrm{OH})_{2}$ produces a superficial pulp necrosis and forms calcium carbonate, whose globules act, in a first moment, as dystrophic calcification nucleolus, in the margin and in the interior of the dense reticular fibre deposition, immediately beneath
Table 4. Kruskal Wallis analyses of soft tissue responses. Data from incisors examined 28-day following the pulp capping procedure is shown. The values of soft tissue scores are mean, standard deviation values for the number of subjects listed under Sample. In general the lower score is the better in tissue response. Calcium hydroxide $\left(\mathrm{Ca}(\mathrm{OH})_{2}\right)$, enamel matrix derivative (EMD), mineral trioxide aggregate (MTA), and platelet rich plasma (PRP).

\begin{tabular}{cccccc}
\hline \multirow{2}{*}{ 28-Day } & $\boldsymbol{n}$ & \multicolumn{2}{c}{ Inflammation } & Hyperemia & Necrosis \\
\cline { 3 - 5 } & & Type & Intensity & & \\
\hline PRP & $\mathbf{1 2}$ & $1.70 \pm 1.06^{\mathrm{a}}$ & $1.80 \pm 0.79^{\mathrm{c}}$ & $1.88 \pm 0.83^{\mathrm{d}}$ & $0.18 \pm 0.40^{\mathrm{t}}$ \\
EMD & $\mathbf{1 2}$ & $1.25 \pm 0.89^{\mathrm{b}}$ & $1.19 \pm 0.25^{\mathrm{x}}$ & $1.22 \pm 0.48^{\mathrm{e}}$ & $0.39 \pm 0.49^{\mathrm{y}}$ \\
MTA & $\mathbf{1 2}$ & $1.60 \pm 1.26^{\mathrm{a}}$ & $1.59 \pm 0.67^{\mathrm{c}}$ & $1.80 \pm 0.79^{\mathrm{d}}$ & $0.39 \pm 0.17^{\mathrm{y}}$ \\
$\mathbf{C a ( O H})_{2}$ & $\mathbf{1 2}$ & $1.32 \pm 0.91^{\mathrm{b}}$ & $1.56 \pm 0.73^{\mathrm{c}}$ & $1.90 \pm 0.74^{\mathrm{d}}$ & $0.45 \pm 0.25^{\mathrm{y}}$ \\
\hline
\end{tabular}

The same superscript letters are demonstrated no significant differences ( $p<$ $0.05)$.

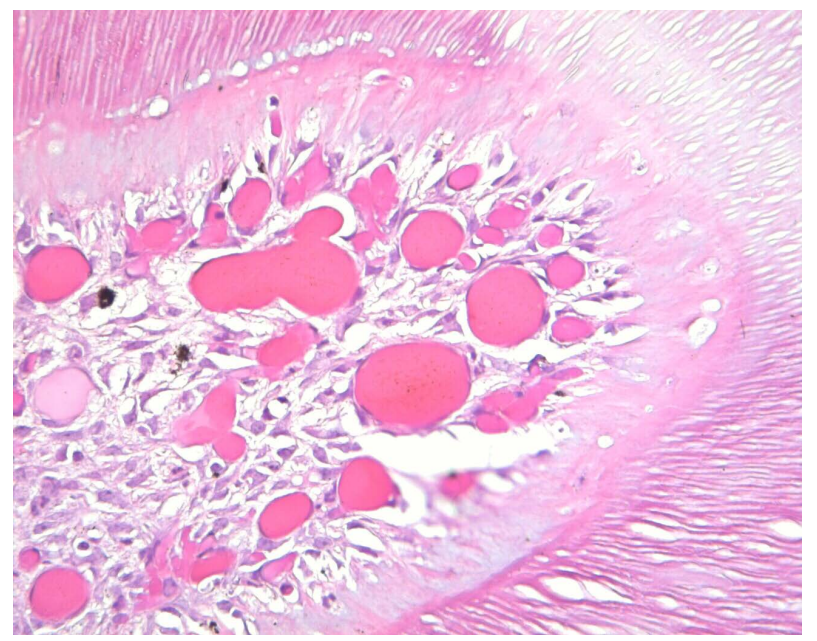

Figure 4. Representative photograph is incisor tooth of rat dental pulp in EMD group at 28-day. Note the mild congestion of capillary, regular odontoblastic arrangement is seen. In this specimen revealed small foreign bodies embedded in reparative dentin means rapid dentinogenesis in the rat dental pulp tissue $(H \&$ E stain: original magnification $\times 100$ ).

the granular zone [30], where odontoblast-like cells differentiate and organize to produce dentin.

EMD is obtained from developing porcine tooth buds. It contains an amelogenin and amelin protein-rich fraction, and is available in gel form with propylene glycol alginate as a vehicle (Emdogain; Biora, Malmö, Sweden). This biomaterial has been shown to be clinically resistant, because amelogenin and amelin are recognized as "autoproteins" by the human defense system, and no allergic or immunologic reactions have been reported during $10+$ years of use [32]. Amelogenin and amelin are structural proteins in the enamel matrix that play an important role in enamel formation [33]. It is believed that enamel matrix proteins participate in the reciprocal ecto-mesen- 
chymal signaling that controls this process [12]. The mechanism by which EMD influences the cell function is still unknown, and few studies have reported the effects of EMD on dental pulp [17-19]. According to our study and other similar studies [17], it seems that the use of EMD has better score results in terms of inflammatory response than the use of $\mathrm{Ca}(\mathrm{OH})_{2}$ in rat dental pulps (Tables 3 and 4).

In animal studies using PRP, when chancellors bone from the iliac crest was used as the graft material for sinus lifts with or without PRP, biopsies showed both PRP and control groups achieved similar results with no statistically significant difference between the two [34, 35]. Similar findings were also reported when PRP was added to the xenograft [36] (e.g., Bovine HA). These results are consistent with those above that failed to demonstrate enhanced bone regeneration when PRP is combined with non-living graft materials.

In minipigs [33], and adult domestic pigs [37] controlled studies demonstrated enhanced healing and bone regeneration with the PRP application. A short-term increase (e.g., improved at 2 weeks but not at least 12 weeks) of bone regeneration in sinus augmentation was observed when compared to the Beta-TCP with or without PRP [38]. One concern is the use of bovine thrombin in activating the PRP release to cause immunogenic reaction [39]. Moreover, PRP group that showed the highest degree of inflammation both in 7 and 28 days. In contrast, only the PRP group presented the lowest scores of necrosis $(p<0.05)$, comparison of 28-day samples in our study.

It is well-known that low concentrated $\mathrm{Ca}(\mathrm{OH})_{2}$ induces the proliferation of pulp fibroblasts [40]. It can be assumed that MTA has the same effects because of the release of calcium and hydroxyl ions when in contact with water or tissue fluids. Takita et al. [41] compared the effects of MTA and $\mathrm{Ca}(\mathrm{OH})_{2}$ on human pulp cells in an in vitro study. Compared with the control group MTA stimulated the proliferation of cells significantly within 12 days, whereas $\mathrm{Ca}(\mathrm{OH})_{2}$ showed no such effect. The amount of calcium ions released by MTA was significantly higher when compared with Dycal. When the cell cultures got in contact with calcium ions at different concentration levels, the cell proliferation counts mirrored these different levels. The release of calcium ions from MTA might induce the proliferation of human pulp cells [41]. The present histologic study in rats undertaken 7 - 28 days after direct pulp capping showed that MTA produced similar good results when compared with $\mathrm{Ca}(\mathrm{OH})_{2}$, in terms of tissue necrosis and hyperemia. These results relate to MTA characteristics. These characteristics are nonresorbable, minimum cytotoxicty, excellent marginal adaptation, high pH setting after 3 - 4 hours, and reliable cytokine production in human osteoblasts [42].

\section{CONCLUSIONS}

The characteristic inflammations of pulp tissue, observed in this study, suggest that PRP can induce or promote inflammatory processes and continue to survive in the wounded rat dental pulp. However, more investigations are needed to understand the inflammatory characteristics of PRP-promoted healing in dental pulps.

In the limitation of the study PRP can induce inflammatory effect on the pulp tissue of rat teeth. DPC with PRP can cause cell accumulation, despite with low necrosis risk. Bewaring of EMD can cause necrosis after DPC. EMD and PRP might serve as pulp capping biomaterials to induce initial healing response in the future.

\section{ACKNOWLEDGEMENTS}

This Project labeled “1949-D-09” has been supported by Süleyman Demirel University, Division of Scientific Research and Coordination of Projects.

\section{REFERENCES}

[1] Zander, H.A. (1939) Reaction of the pulp calcium hydroxide. Journal of Dental Research, 18, 373-379. http://dx.doi.org/10.1177/00220345390180040601

[2] Kozlov, M. and Massler, M. (1966) Histologic effects of various drugs on amputated pulps of rat molars. Oral Surgery, 13, 455-469. http://dx.doi.org/10.1016/0030-4220(60)90351-0

[3] Dammaschke, T. (2008) The history of direct pulp capping. Journal of HistoricalDentistry, 56, 9-23.

[4] Weider, S.R., Schour, I. and Mohammed, C.I. (1956) Reparative dentin following cavity and fillings in the rat molar. Oral Surgery, 9, 221-222. http://dx.doi.org/10.1016/0030-4220(56)90103-7

[5] Rutherford, B. and Spangberg, L. (1995) Transdentinal stimulation of reparative dentin formation by osteogenic protein-1 in monkeys. Achieves of Oral Biology, 40, 681683. http://dx.doi.org/10.1016/0003-9969(95)00020-P

[6] Murray, P.E., About, I., Franquin, J.-C., Remsuat, M. and Smith, A.J. (2001) Restorative pulpal and repair responses. Journal of American Dental Association, 132, 482490.

[7] Pitt Ford, T.R., Torabinejad, M., Abedi, H.R., Bakland, L.K. and Kariyawasam, S.P. (1996) Using mineral oxide aggregate as a pulp capping material. Journal of American Dental Association, 127, 1491-1494.

[8] Abedi, H.R., Torabinejad, M., Pitt Ford, T.R. and Bakland, L.K. (1996) The use of mineral trioxide aggregate cement (MTA) as a direct pulp capping agent. Journal of Endodontics, 22, 199.

[9] Junn, D.J., McMillan, P., Bakland, L.K. and Torabinejad, M. (1998) Quantitive assessment of dentin bridge formation following pulp capping with mineral trioxide aggregate (MTA). Journal of Endodontics, 24, 278-288.

[10] Yuan, K., Chen, C.L. and Lin, M.T. (2003) Enamel ma- 
trix derivative exhibits angiogenic effect in vitro and in a murine model. Journal of Clinical Periodontology, 30, 732-738.

http://dx.doi.org/10.1034/j.1600-051X.2003.00413.x

[11] Nakamura, Y., Hammarström, L., Matsumoto, K. and Lyngstadaas, S.P. (2002) The induction of reparative dentin by enamel proteins. International Endodontic Journal, 35, 407-417.

http://dx.doi.org/10.1046/j.1365-2591.2002.00556.x

[12] Hammarström, L. (1997) Enamel matrix, cementum development and regeneration. Journal of Clinical Periodontology, 24, 658-668. http://dx.doi.org/10.1111/j.1600-051X.1997.tb00247.x

[13] Heijl, L., Heden, G., Svardstrom, G. and Ostegren, A. (1997) Enamel matrix derivative (Emdogain) in the treatment of intrabony periodontal defects. Journal of Clinical Periodontology, 24, 705-714. http://dx.doi.org/10.1111/j.1600-051X.1997.tb00253.x

[14] Esposito, M., Grusovin, M.G., Coulthard, P. and Worthington, H.V. (2005) Enamel matrix derivative (Emdogain) for periodontal tissue regeneration in intrabony defects. Cochrane Database System Review, 19, CD003875.

[15] Lyngstadaas, S., Lundberg, E., Ekdahl, H., Andersson, C. and Gestrelius, S. (2001) Autocrine growth factors in human periodontal ligament cells cultured on enamel matrix derivative. Journal of Clinical Periodontology, 28, 181188. http://dx.doi.org/10.1034/j.1600-051x.2001.028002181.x

[16] Lam, K. and Sae-Lim, V. (2004) The effect of Emdogain gel on periodontal healing in replanted monkeys teeth. Oral Surgery Oral Medicine Oral Pathology Oral Radiology and Endodontics, 97, 100-107. http://dx.doi.org/10.1016/S1079-2104(03)00318-4

[17] Nakamura, Y., Hammarström, L., Lundberg, E., Ekdahl, H., Matsumoto, K. and Gestrelius, S. (2001) Enamel matrix derivative promotes reparative processes in the dental pulp. Advanced Dental Research, 15, 105-107. http://dx.doi.org/10.1177/08959374010150010201

[18] Tatsunari, N. and Matsumoto, K. (2003) Histopathological study of dental pulp tissue capped with enamel matrix derivative. Journal of Endodontics, 29, 176-179. http://dx.doi.org/10.1097/00004770-200303000-00003

[19] Igarashi, R., Sahara, T., Shimizu, M. and Sasaki, T. (2003) Porcine enamel matrix derivative enhances the formation of reparative dentin and dentin bridges during wound healing of amputated rat molars. Journal of Electron Microscopy, 52, 227-236. http://dx.doi.org/10.1093/jmicro/52.2.227

[20] Smith, A.J., Tobias, R.S. and Cassidy, N. (1994) Odontoblast stimulation in ferrets by dentin matrix components. Achieves Oral Biology, 39, 13-22. http://dx.doi.org/10.1016/0003-9969(94)90029-9

[21] Sloan, A.J. and Smith, A.J. (1999) Stimulation of the dentin-pulp complex of rat incisor teeth by transforming growth factor-beta isoforms 1-3 in vitro. Achieves Oral Biology, 44, 149-156. http://dx.doi.org/10.1016/S0003-9969(98)00106-X

[22] Marx, R.E. and Garg, A.K. (1998) Bone structure, metabolism, and physiology: Its impact on dental implantolo- gy. Implant Dentistry, 7, 267-276. http://dx.doi.org/10.1097/00008505-199807040-00004

[23] Anitua, E. (1999) Plasma rich in growth factors: Preliminary results of use in the preparation of future sites/or implants. International Journal of Oral \& Maxillofacial Implants, 14, 529-535.

[24] Gerard, D., Carlson, E.R., Goteher, J.E. and Jaeobs, M. (2006) Effects of platelet-rich plasma on the healing of autologous bone grafted mandibular defects in dogs. Journal of Oral \& Maxillofacial Surgery, 64, 443-445. http://dx.doi.org/10.1016/j.joms.2005.11.016

[25] Hasheminia, S.M., Feizi, G., Razavi, S.M., Feizianfard, M., Gutknecht, N. and Mir, M. (2010) A comparative study of three treatment methods of direct pulp capping in canine teeth of cats: A Histologic evaluation. Lasers Medical Sciences, 25, 9-15. http://dx.doi.org/10.1007/s10103-008-0584-9

[26] Obersztyn, A. (1965) A new method for testing drugs used in direct pulp capping on a rat incisor as an experimental model. Czas Stomatology, 18, 213-220.

[27] Hu, J.C.C., Zhang, C., Yun, S.S., Qian, Q. and Ranly D.D.M. (1997) Platelet derived growth factor-BB and epidermal growth factor as pulp capping medicaments in rat incisors. Journal of Hard Tissue Biology, 6, 121-129.

[28] Sloan, A.J. and Smith, A.J. (1999) Stimulation of the dentin-pulp complex of rat incisor teeth by transforming growth factor-beta isoforms 1-3 in vitro. Achieves Oral Biology, 44, 149-156. http://dx.doi.org/10.1016/S0003-9969(98)00106-X

[29] Hebling, J., Giro, E.M. and Costa, C.A. (1999) Biocompatibility of an adhesive system applied to exposed human dental pulp. Journal of Endodontics, 25, 676-682. http://dx.doi.org/10.1016/S0099-2399(99)80354-9

[30] Holland, R. (1971) Histochemical response of amputes pulps to calcium hydroxide. Pesquisa Odontológica Brasileira, 4, 83-95.

[31] Modena, K.C., Casas-Apayco, L.C., Atta, M.T., Costa, C.A., Hebling, J., Sipert, C.R., Navarro, M.F. and Santos, C.F. (2009) Cytotoxicity and biocompatibility of direct and indirect pulp capping materials. Journal of Applied Oral Science, 17, 544-554. http://dx.doi.org/10.1590/S1678-77572009000600002

[32] Wilson, T. (1999) Safety testing of Emdogain. In: Wilson, T., Ed., Periodontal Regeneration Enhanced, Quintessence, Chicago, 23-25.

[33] Hu, J.C.C., Sun, X., Zhang, C. and Zimmer, J.P. (2001) A comparison of enamelin and amelogenin expression in developing mouse molar. European Journal of Oral Science, 109, 125-132. http://dx.doi.org/10.1034/j.1600-0722.2001.00998.x

[34] Jakse, N., Tangl, S., Gilli, R., Berghold, A., Lorenzoi, M., Eskici, A., Haas, R. and Pertl, C. (2003) Influence or PRP on autogenous sinus grafts. An experimental study on sheep. Clinical Oral Implants Research, 14, 578-583. http://dx.doi.org/10.1034/j.1600-0501.2003.00928.x

[35] Butterfield, K.J., Bennett, J., Gronowicz, G. and Adams, D. (2005) Effect of platelet-rich plasma with autogenous bone graft for maxillary sinus augmentation in a rabbit 
model. Journal of Oral \& Maxillofacial Surgery, 63, 370376. http://dx.doi.org/10.1016/j.joms.2004.07.017

[36] Furst, G., Gruber, R., Tangl, S., Zechner, W., Haas, R., Mailath, G., Sanroman, F. and Watzek, G. (2003) Sinus grafting with autogenous platelet-rich plasma and bovine hydroxyapatite. A histomorphometric study in minipigs. Clinical Oral Implants Research, 14, 500-508. http://dx.doi.org/10.1034/j.1600-0501.2003.00859.x

[37] Thorwarth, M., Wehrhan, F., Schultze-Mosgau, S., Wiltfang, J. and Schlegel, K.A. (2006) PRP modulates expression of bone matrix proteins in vivo without longterm effects on bone formation. Bone, 38, 30-40. http://dx.doi.org/10.1016/j.bone.2005.06.020

[38] Wiltfang, J., Schlegel, K.A., Schultze-Mosgau, S., Nkenke, E., Zimmermann, R. and Kessler, P. (2003) Sinus floor augmentation with $\beta$-tricalciumphosphate $(\beta$-TCP): Does platelet-rich plasma promote its osseous integration and degradation? Clinical Oral Implants Research, 14, 213218. http://dx.doi.org/10.1034/j.1600-0501.2003.140212.x

\section{ABBREVIATIONS}

Calcium Hydroxide $\left(\mathrm{Ca}(\mathrm{OH})_{2}\right)$;

Enamel Matrix Derivative (EMD);
[39] Landesberg, R., Moses, M. and Karpatkin, M. (1998) Risks of using platelet rich plasma gel. Journal of Oral \& Maxillofacial Surgery, 56, 1116-1117. http://dx.doi.org/10.1016/S0278-2391(98)90286-5

[40] Torneck, C., Moe, H. and Howlwy, T.P. (1983) The effect of calcium hydroxide on porcine pulp fibroblasts in vitro. Journal of Endodontics, 9, 131-136. http://dx.doi.org/10.1016/S0099-2399(83)80031-4

[41] Takita, T., Hayashi, M., Takeichi, O., Ogiso, B., Suzuki, N., Otsuka, K. and Ito, K. (2006) Effect of mineral trioxide aggregate on proliferation of cultured human dental pulp cells. International Endodontic Journal, 39, 415-422. http://dx.doi.org/10.1111/j.1365-2591.2006.01097.x

[42] Zhu, Q., Haglund, R., Safave, K.E. and Spangberg, L.S.W. (2000) Adhesion of human osteoblasts on root ending filling materials. Journal of Endodontics, 26, 404406.

http://dx.doi.org/10.1097/00004770-200007000-00006
Mineral Trioxide Aggregate (MTA); Platelet Rich Plasma (PRP). 